\title{
LEUKOCYTE DIFFERENTIAL OF ANGUILLID EEL, Anguilla bicolor McClelland, EXPOSED TO VARIED SALINITIES
}

\author{
Fita Fatimah, FARida Nur RachmaWati, Eko SETio Wibowo
}

Fakultas Biologi, Universitas Jenderal Soedirman, Jalan dr. Suparno 63 Purwokerto 53122

\section{A B S T R A C T}

The anguillid eel is a catadromous eel capable of inhabiting freshwater growth habitat and seawater spawning habitat throughout their life cycle. At the juvenile to mature stage, they inhabit freshwater then migrate to marine water to spawn. Changes in salinity, which is one of the stressful environmental factors for the eel, affect their physiological condition by increasing the leukocytes number. This increase is an adaptation method to improve their immune system as a response to salinity change. This study intended to evaluate the leukocyte differential of anguillid eel (Anguilla bicolor McClelland) exposed to various salinities. This research applied a Completely Randomized Design. The treatment was three levels of saline media including $4 \mathrm{ppt}, 15 \mathrm{ppt}$, and $30 \mathrm{ppt}$ with five replicates. The independent variable was the different salinity, and the dependent variable was the leukocyte differential. The parameters measured consisted of the different percentage of neutrophils, lymphocytes, monocytes, and eosinophils in which the measurements administered after two months of the eel exposure. We analyzed the data with ANOVA at the confidence level of 95\%. The results showed that exposure of salinity significantly affected the percentage of leukocyte differential $(\mathrm{P}<0.05)$. The increase in salinity decreased the neutrophils and monocytes, but increased the lymphocytes, and showed no effect on eosinophils.

KEY WoRDS: Anguilla bicolor McClelland, leukocyte differential, salinity

Corresponding Author: FARIDA NUR RACHMAWATI| email: faridanur12@gmail.com

\section{NTRODUCTION}

The anguillid eel is a potential fish to cultivate. In Indonesia, it is known as Sidat, according to Haryono (2008) it is also known as moa, lubang, and uling (in West Java), pelus (in Central Jawa), and 'Eared- Eel' because of the pectoral fin which resembles an earlobe structure. It has a high economic value and is an export commodity in the fishery sector. The request for anguillid eel in markets can reach up to 500.000 tons per year and is mostly from Japan and Korea (Purwanto, 2007). The anguillid eel has a wide distribution range, for they are divided into tropical, and subtropical anguillid eel. There are at least 17 species of anguillid eel, and six species are in Indonesia. They include the Anguilla marmorata, $A$. celebensis, A. ancentralis, A. borneoensis, A. bicolor bicolor and A. bicolor pacifica. The A. bicolor is the only species that successfully cultivated in Indonesia (Affandi, 2005).

The anguillid eel cultivation in Indonesia is limited to grow out culture because their unique life cycle hampers the reproduction technique to be completely understood. The anguillid eel is a catadromous fish inhabiting two different waters, in term of salinity, throughout its life cycle. Throughout its juvenile and mature stage, it inhabits fresh waters. Whereas during spawning stage, it migrates to the marine waters (Sudo et al., 2013). According to Haryono (2008), spawning occurs at depths of $400-500 \mathrm{~m}$ with temperatures of $16-17^{\circ} \mathrm{C}$ and salinities of $35 \mathrm{ppt}$. The migration of anguillid eel from fresh waters to the sea with a high difference salinity indirectly affects the physiological condition of the fish.

The anguillid eel used in this research was those in the silver eel stadium which inhabited fresh waters and was ready to migrate to the sea to spawn.
According to Herianti (2005), extreme exposure to high salinities can affect the physiological condition of fish. They need time to adapt, survive, and perform physiological processes. Alteration of the fish physiological conditions might cause changes in blood components.

Salinity affects the osmoregulation system in fish. Osmoregulation is the process of regulating osmotic pressure between the organism body and the media. Marine organisms require to adapt to the osmotic pressure of their environment, and those do not adapt encounter stress and die (Sobirin et al., 2014). According to Royan et al. (2014), different salinities cause an alteration in the blood profile (decrease in hematocrit, hemoglobin, total erythrocyte, increase in blood glucose and leukocyte) and decrease fish survival as the salinity increase.

Stress animals adapt various ways to survive, for example, by increasing the amount of leukocyte as a response to salinity changes. Rise in leukocyte due to stress might serve as adaptation indicator and resistance towards external disturbances (Isroli, 2002).

The response of blood profile is to increase the fish immunity to which adjusting of leukocytes increases body defense mechanism (Suprayudi et al., 2006). The effect of salinity towards the fish physiological condition can be observed from the leukocyte differential (Verdegem et al., 2008). According to Gross \& Siegel (1983), the comparison between monocytes, neutrophils, and lymphocytes, is an excellent indicator to measure the organism stress level. The purpose of this research was to evaluate the differential in leukocytes of anguillid eel (A. bicolor McClelland) due to the exposure of different salinities. 


\section{METHODS}

Tools used in this research were tarpaulin cloth tanks, fiber tanks, aerator, light microscope, object glass, scissors, scale, and hand refractometer. Materials consisted of silver stage anguillid eel Anguilla bicolor McClelland, seawater, freshwater, labels, tissue, distilled water, earthworms, Giemsa 7\% and methanol PA. We conducted the experiments at the Experimental Station, and the Laboratory of Animal Physiology, Faculty of Biology, Universitas Jenderal Soedirman from October 2015 until March 2016.

This research applied a Complete Randomized Design with three salinity treatments and five replicates (15 units). Salinity levels of the growth media were based on Royan et al. (2014) as follows:

\section{$\mathrm{A}=4 \mathrm{ppt}$ (control) \\ $\mathrm{B}=15 \mathrm{ppt}$ \\ $\mathrm{C}=30 \mathrm{ppt}$}

The observation of leukocyte profile was conducted after two months exposure. The independent variables were the media of various salinities, whereas the dependent variable was the leukocyte differential. The parameters measured were the percentage of leukocyte differential of the anguillid eel.

The fish were placed in three units of tarpaulin cloth tanks with the size of $130 \times 100 \times 100 \mathrm{~cm}^{3}$ equipped with aerators. Each tank was cleaned before use to prevent the growth of molds and fungi. The preparation of media salinity (4 ppt, 15 ppt, and $30 \mathrm{ppt}$ ) followed Setyo (2006):

$$
S n=\frac{\mathrm{S} 1 . \mathrm{V} 1+\mathrm{S} 2 \cdot \mathrm{V} 2}{V 1+V 2}
$$

where,

$\mathrm{Sn}=$ Salinity level intended

S1 = Salinity of stock water

$\mathrm{S} 2$ = Salinity of mixed freshwater

$\mathrm{V} 1=$ Volume of stock water

$\mathrm{V} 2=$ Volume of mixed freshwater

The fish silver stadium (15 individuals) with an average body length of $60 \mathrm{~cm}$ and an average weight of $480 \mathrm{~g}$ were selected. The fish were from Pesanggrahan Village, District of Cilacap, and were healthy, had no disabilities, and active.

The fish were acclimated for at least one week in a fiber tank measuring $70 \mathrm{~cm}$ in height and $125 \mathrm{~cm}$ in diameter. The fish exposed to high salinities required to acclimate gradually from $4 \mathrm{ppt}, 10 \mathrm{ppt}, 15 \mathrm{ppt}$, and $30 \mathrm{ppt}$ for one week in each level of salinity. As many as eight fish were placed in one tube containing media. The fish were fed with earthworms once a day on ad libitum at $16.00 \mathrm{pm}$. The exposure allowed for two months. The aeration and salinity in each tub were regularly controlled to ensure the efficient oxygen circulation and maintain the right level of salinity.

The fish weight was measured with a scale, whereas the length was measured using a measuring tape. The blood was taken by cutting the caudal fin and placed in on an object glass to smear. The blood smear method followed Anderson \& Siwicki (1993). The object glass used was immersed in methanol to remove any excess fat. The blood was dropped on the object glass and smeared using another object glass with an angle of $45^{\circ}$ and dried. The dried smear was then fixed with methanol for 3-5 minutes then dyed with Giemsa for 20-30 minutes, washed and dried. We observe the smear under a microscope at 400x magnification. Each type of leukocyte was calculated up to the 100th cells (Kurniawan et al., 2013).
$\%$ neutrophil = number of neutrophil counted (100) $\times 100 \%$ $\%$ lymphocyte = number of lymphocyte counted $(100) \times 100 \%$ $\%$ monocyte = number of monocyte counted (100) $\times 100 \%$ $\%$ eosinophil = number of eosinophil counted $(100) \times 100 \%$

The data was analyzed with ANOVA at 5\% degree of error to measure the significant difference of salinity on the anguillid eel Anguilla bicolor McClelland leukocyte differential. If ANOVA showed a significant difference, then the analysis was continued to the LSD (Harjosuwono et al., 2011).

\section{RESULTS AND DISCUSSION}

Figure 1. represented the differential leukocyte of anguillid eel ( $A$. bicolor). The fish neutrophil reached $25 \pm 4.30 \%, 21.8 \pm 2.39 \%$ and $9.8 \pm 1.79 \%$ for salinity of 4,15 , and 30 ppt respectively. The fish neutrophil levels of 4 and 15 ppt coincided with Utami et al. (2013), who reported the neutrophil of Nile tilapia fish of $18-27 \%$ when exposed to freshwater salinity. The neutrophil decreased when the fish were in 30 ppt salinity. However, this neutrophil amounts fell between the normal range of marine fish. Johnny et al. (2003) claimed that the neutrophil of marine fish such as grouper was between 6 and 11\%.

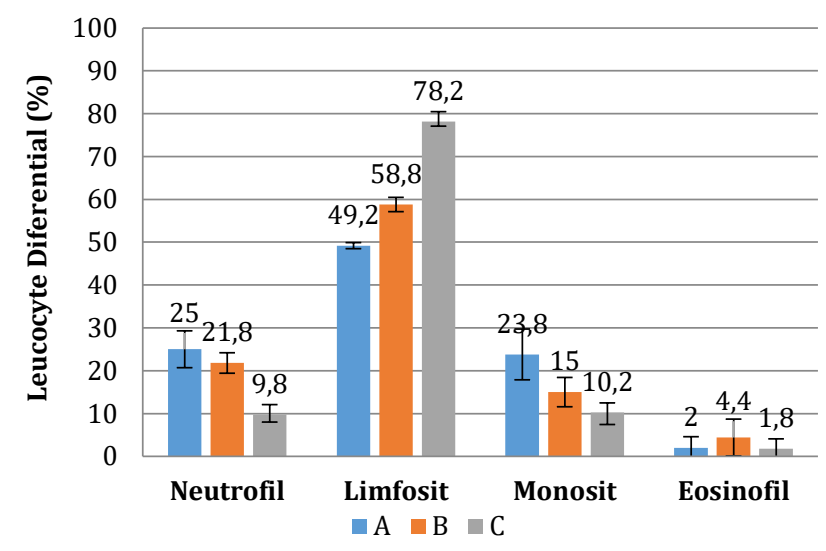

Figure 1. The average percentage of leukocyte differential of anguillid eel exposed to (A) 4 ppt salinity (control), (B) 15 ppt salinity, (C) $30 \mathrm{ppt}$ salinity. The different alphabet notation above the numbers showed a significant difference $(\mathrm{P}<0.05)$.

The ANOVA showed a significant difference of neutrophil in the fish exposed in three different salinities $(\mathrm{P}<0.05)$. This result indicated that salinity affected the amount of neutrophil. Neutrophil decreased as the salinity increased. According to Davis et al. (2008), the neutrophil decline might be due to fish adaptation to their environmental alteration. When the fish adapted to the change, cortisol levels within the blood decreased, resulted in the neutrophil decrease.

The LSD revealed the fish neutrophil of 4 and 15 ppt salinities was not significantly different $(\mathrm{P}<0.05)$, whereas the salinity of $30 \mathrm{ppt}$ showed a significant difference $(\mathrm{P}<0.05)$ between the salinities. The decrease of neutrophil in the 30 ppt salinity most likely was because of the lymphocyte increase during the treatment. The neutrophil level within each 
salinity was relatively similar to that of other fish inhabiting the given salinity. Suprayudi et al. (2006) stated that salinity was one of many abiotic factors affecting the leukocyte differential in fish. Salinity stress might cause a high increase in leukocyte and result in the increase of lymphocyte. The lymphocyte increase stimulated neutrophil decrease. This result coincided with Erika (2008) who stated that the neutrophil decrease might occur due to the balancing mechanism of other proportions of leukocytes such as the lymphocyte.

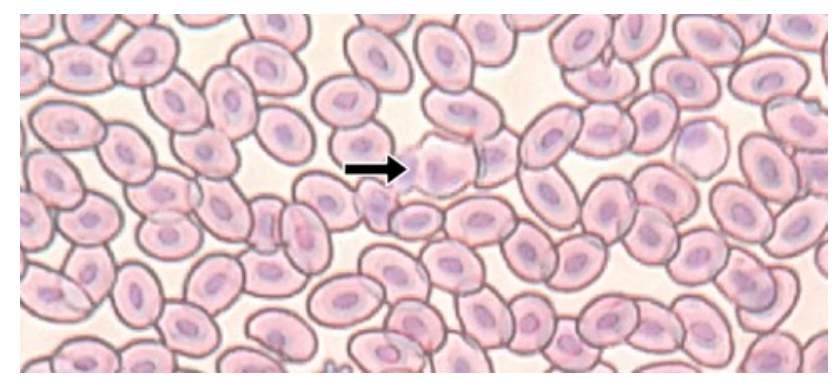

Figure 2. Neutrophil (N) (arrow) of anguillid eel Anguilla bicolor McClelland (400x)

The anguillid eel lymphocyte exposed to salinities of 4,15 , and 30 ppt were $49.2 \pm 5.93 \%, 58.8 \pm 3.42 \%$ and $78.2 \pm 2.77 \%$ respectively. The lymphocyte increased as the salinity increased. These results were similar to Sugito et al., (2014). They measured the lymphocyte level of the freshwater fish that ranged between 42 and 51\%. Further, brackish fish showed the lymphocyte between 60 and $70 \%$, and marine fish between 60 and $80 \%$ (Hartika et al., 2011). The ANOVA showed a significant difference in the lymphocyte percentage between anguillid eel exposed to different salinities $(\mathrm{P}<0.05)$. This result demonstrated that salinity most likely influenced the lymphocyte amount. The increase in lymphocyte suggested adaptation towards the salinity change in the fish environment. Lymphocyte of the anguillid eel resembled the lymphocyte amount of other fishes in the given waters. Moyle \& Cech (2004), reported that the immune system responded to external interferences, such as alteration in salinity, with the increase of lymphocyte amount. According to Sakai (1999), the amount of lymphocyte could increase during stress. Stress interfered non-specific immune responses, such as lymphocyte proliferation (increase in cell amount and alterations into T cells and B cells).

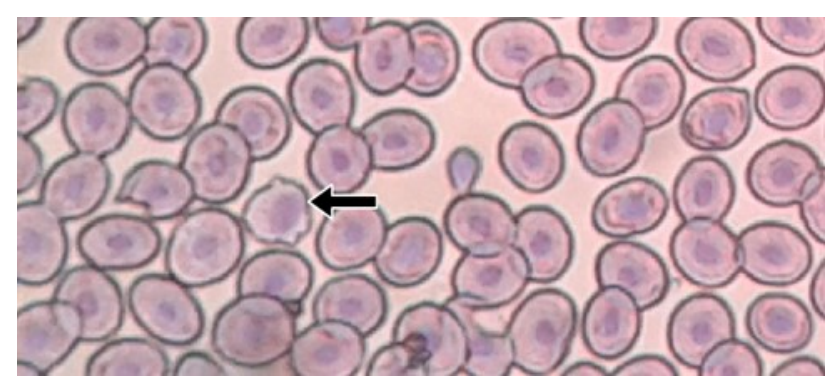

Figure 3. Lymphocyte (arrow) of anguillid eel Anguilla bicolor McClelland (400x)
The LSD demonstrated significant result for lymphocyte of each treatment $(\mathrm{P}<0.05)$. This result suggested that each salinity had a possible effect on lymphocyte amount. As explained by Davis et al. (2008) that to overcome stress, fish had to adapt. One type of which was to increase their lymphocyte level as a response to environment stressors such as changes in temperature, salinity, and density.

Leukocyte increase was related to the decrease in cortisol levels in the body. When cortisol level decreased, DNA synthesis of the lymphocyte cells occurred and led to the high amount of lymphocyte. According to Inoue et al. (2008), in several aquatic animals, increase in the ratio of lymphocyte and neutrophil could be used as an indicator of long-term stress levels of the animal (chronically). Fujaya (2004) mentioned that lymphocytes in the fish body were not phagocytic but hold a major role in the formation of antibodies. The decrease in lymphocyte amount could lead to a reduction in antibodies and prone to disease.

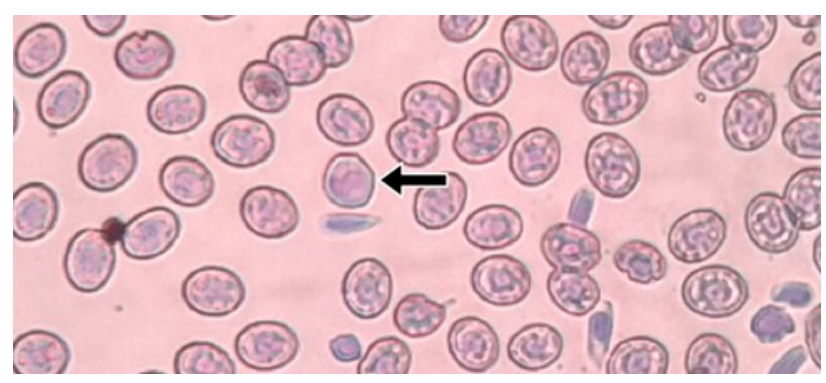

Figure 4. Monocyte (arrow) of anguillid eel Anguilla bicolor McClelland (400x)

The average monocyte in 4,15 , and $30 \mathrm{ppt}$ salinities were $23.8 \pm 2.59 \%, 15 \pm 4.30 \%$ and $10.2 \pm$ $2.28 \%$ respectively. Monocyte decreased with the increase of salinity. Sugito et al. (2014) claimed that monocyte percentage of Nile tilapia fish ranged between 17 and 25\% when presented in freshwater. Monocyte of marine fish such as groupers was 9-15\% (Agung et al., 2013). According to Kurniawan et al. (2013), a decrease in monocyte could be caused by the increase in lymphocyte amount that produced antibodies, therefore led to an obstruction of the monocyte production. The production of antibodies was crucial for the immune system.

ANOVA demonstrated a significant difference $(\mathrm{P}<$ 0.05) between anguillid eel exposed to different salinities. The monocyte decreased when the salinity increased. According to Moyle \& Cech (2004), a decline in monocyte possibly was because monocytes were short-lived (14-36 hours in the blood system). They moved to the tissues and differentiated into macrophages. Putri (2003) stated that phagocytic activity of macrophages was the initial step of the next phase in immunity response, the antibody production.

LSD showed no significant difference $(\mathrm{P}<0.05)$ in monocyte level of 15 and 30 ppt salinities. However, salinities 15 and 30 ppt differed significantly $(\mathrm{P}<$ 0.05 ) from the 4 ppt salinity. Monocyte amount in salinities 15 and 30 ppt was smaller than that of 4 ppt. 
According to Utami et al. (2006), a decrease in monocyte might occur because of the blood equilibrium response to the increase of lymphocyte. The monocyte level showed similar values for fish in the given environment. This result indicated that anguillid eel adapted to a wide range of salinity.

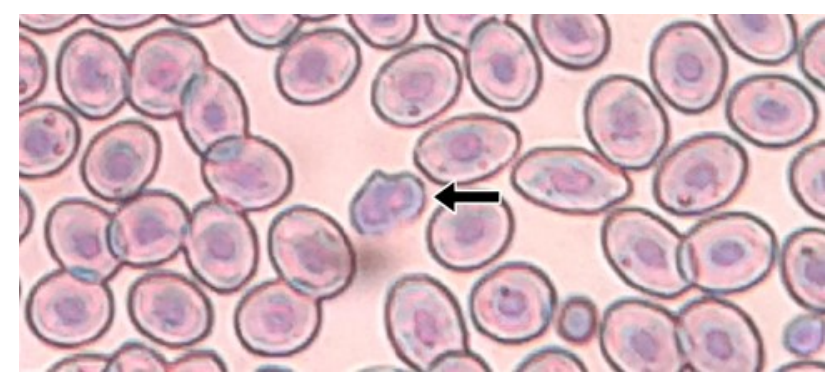

Figure 5. Eosinophil (arrow) of anguillid eel Anguilla bicolor McClelland (400x)

The eosinophil in salinities of 4,15 , and $30 \mathrm{ppt}$ were $2 \pm 0.71 \%, 4.4 \pm 1.67 \%$ and $1.8 \pm 1.10 \%$ respectively. Eosinophil in the salinity of 4 ppt was lower than that of $15 \mathrm{ppt}$, and the lowest was in 30 ppt salinity. Nevertheless, the eosinophil of 4 ppt, 15 ppt, and 30 ppt was within the normal range. According to Salasia et al. (2001), eosinophil of freshwater fish such as goldfish and catfish were 2$8 \%$. In euryhaline fishes such as Nile tilapia, the eosinophil was between 1 and 3\% (Mahasri et al., 2011). According to Satyaningtijas et al. (2010), when animals encountered stress, cortisol levels within the body increased. The increased cortisol levels could cause eosinopenia, which led to a decrease in eosinophil percentage.

ANOVA showed a significant difference of eosinophil between anguillid eel exposed to different salinities $(\mathrm{P}<0.05)$. Further, LSD test revealed that the fish eosinophil in salinities of 4 and 30 ppt did not differ significantly $(\mathrm{P}<0.05)$. However, fish of 4 and $30 \mathrm{ppt}$ showed a significant difference in the salinity of 15 ppt in eosinophil level $(\mathrm{P}<0.05)$. The percentage of eosinophil in this research fell within the normal range. Percentage of eosinophil in marine fish were less studied. The eosinophil amount in the blood circulation system of fish was very low and did not species specific (Nabib \& Pasaribu, 1989).

This research indicated that leukocyte differential of anguillid eel Anguilla bicolor McClelland) changed after exposed to different salinities. The increase in salinity led to the decrease of neutrophil and monocyte, but the increase of lymphocyte. However, eosinophil level was within the normal range. The percentage of leukocyte differential of anguillid eel in each salinity was relatively similar to that of other fish inhabiting waters with that given salinity. Alteration in the percentage of leukocyte differential indicated of adaptation effort due to the change in salinity of the fish environment.

\section{CONCLUSION}

It was concluded that salinity influenced the leukocyte differential of the anguillid eel Anguilla bicolor McClelland. Increased salinity led to decrease the percentage of neutrophil and monocyte, increase the percentage of lymphocyte, but no effect on eosinophil percentage that fell within the normal range.

\section{REFERENCES}

Abbas AK, Licthman AH, Pillai S. 2010. Cellular and Molecular Immunology. 6th ed. Philadelphia: W. B. Saunders Company.

Affandi R. 2005. Strategi Pemanfaatan Sumberdaya Ikan Anguillid eel, Anguilla Spp. Di Indonesia. Jurnal lktiologi Indonesia. 5(2): 77-81.

Agung LA, Slamet BP, Sarjito. 2013. Pengaruh Pemberian Ekstrak Daun Jeruju (Acanthus ilicifolius) Terhadap Profil Darah Ikan Kerapu Macan (Epinephelus fuscogattus). Journal of Aquaculture Management and Technology. 2(1):87-101

Anderson DP, Siwicki AK. 1993. Basic Hematology and Serology for Fish Health Programs. Proceeding of the Second Symposium on Diseases in Asian Aquaculture Aquatic Animal Health and the Enviroment; 1993 October 25-29; Phuket, Thailand.

Davis AK, Seguin RM, Maerz JC. 2008. The Use of Leukocyte Profiles to Measure Stress in Vertebrates: A Review for Ecologist. Functional Ecology. 22:760-772.

Erika Y. 2008. Gambaran Diferensiasi Leukosit pada Ikan Mujair (Oreochromis mossambica) di Daerah Ciampea Bogor. [Skripsi]. Bogor: Institut Pertanian Bogor.

Fujaya Y. 2004. Fisiologi Ikan: Dasar Pengembangan Teknik Perikanan. Jakarta: Rineka Cipta.

Gross WB, Siegel HB. 1983. Evaluation of The Heterefil/Lymphocite Ratio of Measure in Chickens. Avian Disease. 27(4): 972-979.

Harjosuwono BA, Arnata IW, Puspawati GAKD. 2011. Rancangan Percobaan Teori, Aplikasi SPSS dan Excel. Malang: Lintas Kata Publishing.

Hartika R, Mustahal, Achmad NP. 2014. Gambaran Darah Ikan Nila (Oreochromis niloticus) dengan Penambahan Dosis Prebiotik yang Berbeda dalam Pakan. Jurnal Perikanan Dan Kelautan. 4(4):259-267.

Haryono. 2008. Anguillid eel, Belut Bertelinga: Potensi dan Aspek Budidayanya. Fauna Indonesia. 8(1):22-26.

Herianti I. 2005. Rekayasa Lingkungan Utuk Memacu Perkembangan Ovarium Ikan Anguillid eel (Anguilla bicolor). Oseanologi dan Limnologi. 37:25-41.

Inoue LAKA, Moraes G, Iwama GK, Afonso LOB 2008. Physiological Stress Responses in the Warm-water Fish Matrinxa (Brycon amazonicus) Subjected to a Sudden Cold Shock. Acta Amazonica. 38(4):603-610.

Isroli. 2002. Pengaruh Cekaman Panas Terhadap Gambaran Hematologi Domba Lokal. [Skripsi]. Semarang: Universitas Diponegoro

Johnny F, Tridjoko, Roza D. 2003. Studi Pendahuluan Pengaruh Hormon Steroid Terhadap Keragaan Hematologi Induk Ikan Kerapu Bebek (Cromileptes altivelis). Jurnal Veteriner. 4(4): 127-136

Kurniawan S, Budi P, Sarjito, Angela M. 2013. Pengaruh Ekstrak Daun Sirsak (Annona muricata L) terhadap Profil Darah dan Kelulushidupan Ikan Lele Sangkuriang (Clarias gariepinus Var. Sangkuriang) yang Diinfeksi Bakteri Aeromonas hydrophila. Journal of Aquaculture Management And Technology. 2(4):5062.

Madigan MT, Martinko JM, Stahl DA, Clark DP. 2012. Brock Biology of Microorganisms. 13th ed. San Francisco: Benjamin Cummings.

Mahasri G, Pristita W, Laksmi S. 2011. Gambaran Leukosit Darah Ikan Koi (Cyprinus carpio) yang Terinfestasi Ichthyophthirius multifiliis pada Derajat Infestasi yang Berbeda dengan Metode Kohabitasi. Jurnal Ilmiah Perikanan dan Kelautan. 3(1):91-96.

Moyle PB, Cech JJ. 2004. Fishes An Introduction to Ichtiology. 5th ed. New Jersey: Prentice Hall.

Mundriyanto H, Taufik P, Taukhid. 2002. Respon Histologis Tubuh Kodok (Rana catesbeiana Shaw) Terhadap Infeksi Bakteri Patogen dan Potensi Saccharomyces cerevisiae Sebagai 
Immunostimulan. Jurnal Penelitian Perikanan Indonesia. 8(3):53-63.

Nabib R, Pasaribu FH. 1989. Patologi dan Penyakit Ikan. Bogor: Institut Pertanian Bogor.

Purwanto J. 2007. Pemeliharaan Benih Ikan Anguillid eel (Anguilla bicolor) dengan Padat Tebar yang Berbeda. Jurnal Akuakultur. $6(2)$.

Putri I. 2003. Pengaruh sari buah mengkudu (Morinda citrifolia) terhadap pertumbuhan dan gambaran darah ikan gurame (Osphronemus gouramy). [Skripsi]. Bogor: Fakultas Perikanan IPB.

Roberts RJ. 1989. Fish Pathology. London: Baillere Tindall.

Royan F, Rejeki S, Haditomo AHC. 2014. Pengaruh Salinitas yang Berbeda Terhadap Profil Darah Ikan Nila (Oreochromis niloticus). Journal of Aquaculture Management and Technology. 3(2):109-117.

Sakai M. 1999. Current Research Status of Fish Immunostimulants. Aquaculture. 172(1-2):63-92.

Salasia SIO, Dewi S, Atik R. 2001. Studi Hematologi Ikan Air Tawar. Berkala Ilmiah Biologi. 2(12):710-723

Setyo BP. 2006. Efek Konsentrasi Kromium $\left(\mathrm{Cr}^{+3}\right)$ dan Salinitas Berbeda terhadap Efisiensi Pemanfaatan Pakan Untuk Pertumbuhan Ikan Nila (Oreochromis niloticus). [Tesis] Semarang: Program Pasca Sarjana Universitas Diponegoro.
Sobirin M, Agoes S, Bambang, I. 2014. Pengaruh Beberapa Salinitas terhadap Osmoregulasi Ikan Nila (Oreochormis niloticus). Surabaya: Fakultas Sains dan Teknologi, Universitas Airlangga.

Sudo R, Fukuda N, Aoyama J, Tsukamoto K. 2013. Age and Body Size of Japanese Eels, Anguilla japonica, at the Silver-stage in the Hamana Lake system, Japan. Coastal Marine Science. 36(1):1318.

Sugito, Nurliana, Dwinna A, Samadi. 2014. Diferensial Leukosit dan Ketahanan Hidup pada Uji Tantang Aeromonas hydrophila Ikan Nila yang Diberi Stres Panas dan Suplementasi Tepung Daun Jaloh dalam Pakan. Jurnal Kedokteran Hewan. 8(2):158-163.

Suprayudi MA, Indriatuti L, Setawati M. 2006. Pengaruh Penambahan Bahan-Bahan Imunostimulan dalam Formulasi Pakan Buatan Terhadap Respon Imunitas dan Pertumbuhan Ikan Kerapu Bebek. Jurnal Akuakultir Indonesia. 5(1):77-86.

Utami DT, Slamet BP, Sri H, Ayi S. 2013. Gambaran Parameter Hematologis pada Ikan Nila (Oreochromis niloticus) yang diberi Vaksin DNA Streptococcus iniae dengan Dosis yang Berbeda. Journal of Aquaculture Management And Technology. 2(4):720.

Verdegem MCJ, Hilbrands AD, Bloon JH. 2008. Influeence of Salinity and Dietary Composition on Blood Parameter Values of Hybrid Red Tilapia, Oreochromis niloticus (Linnaeus) X O. mossambicus (Peters). Aquaculture Research. 28:453-459. 